\title{
DETERMINAN PENYERAPAN TENAGA KERJA SEKTOR PARIWISATA KABUPATEN/KOTA PROVINSI JAWA BARAT
}

\author{
Adhitya Wardhana ${ }^{1}$ \\ Bayu Kharisma ${ }^{2}$ \\ Citra Triaryanti ${ }^{3}$
}

\begin{abstract}
Fakultas Ekonomi dan Bisnis Universitas Padjadjaran, Jawa Barat, Indonesia ${ }^{1,2,3}$
Email : adhitya.wardhana@fe.unpad.ac.id ${ }^{1,2,3}$
\end{abstract}

\begin{abstract}
Abstrak
Tujuan penelitian ini akan membahas determinan penyerapan tenaga kerja yaitu jumlah wisatawan, upah minimum, jumlah kamar hotel dan output (PDRB) pariwisata di Jawa Barat. Penelitian ini menggunakan analisis deskriptif dan kuantitatif dari Kabupaten/Kota di Provinsi Jawa Barat. Ruang lingkup dalam penelitian ini yaitu sebanyak 25 Kabupaten/Kota di Jawa Barat dengan periode 2013-2017 dalam bentuk panel data. Model penelitian yang digunakan yaitu model Generalized Least Square. Hasil penelitian ini menunjukkan bahwa jumlah wisatawan, upah minimum dan jumlah kamar hotel mempengaruhi signifikan terhadap penyerapan tenaga kerja sektor pariwisata.
\end{abstract}

Kata kunci : penyerapan tenaga kerja; pariwisata; Kabupaten/kota di Jawa Barat; Generalized Least Square

\begin{abstract}
This paper aims to discuss the determinants of labor absorption, namely the number of tourists, the minimum wage, the number of hotel rooms and the tourism output $(P D R B)$ in West Java. This research uses descriptive and quantitative analysis of the regencies / cities in West Java Province. The scope of this research is as many as 25 regencies / cities in West Java with the 2013-2017 period in the form of data panels. The research model used is the Generalized Least Square model. The results of this study indicate that the number of tourists, the minimum wage and the number of hotel rooms have a significant effect on employment in the tourism sector.
\end{abstract}

Keywords: employment; tourism; regency / city in West Java;Generalized Least Square 


\section{PENDAHULUAN}

Dewasa ini sektor pariwisata berperan meningkatkan perekonomian disuatu daerah. Peranan sektor pariwisata dalam meningkatkan perekonomian daerah melalui devisa (wisatawan asing yang berkunjung), potensi masyarakat setempat dalam menghasilkan barang dan jasa dan memperluas penyerapan tenaga kerja. Penyerapan tenaga kerja pada sektor pariwisata dapat terhubung langsung melalui jasa perhotelan, rumah makan, agen travel. Penyerapan tenaga kerja pariwisata yang tidak terkait secara langsung seperti industri kerajinan, penyediaan produk-produk pertanian, atraksi budaya dan jasa lainnya (Wahab, 2003). Provinsi Jawa Barat memiliki objek wisata yang beragam dari mulai pegunungan hingga pantai. Objek wisata provinsi Jawa Barat didukung oleh ragam kesenian dan budaya yang menjadi daya tarik tersendiri untuk wisatawan. Kota Bandung merupakan Ibukota Provinsi Jawa Barat termasuk dalam 10 Top Destination Branding National. Kementerian Pariwisata (2017), Kota Bandung memiliki potensi peningkatan kunjungan wisatawan mencapai 20 juta pada tahun 2019. Potensi pariwisata Jawa Barat akan berdampak terhadap peningkatan input pariwisata seperti penyerapan tenaga kerja. Pada gambar 1 terlihat adanya penyerapan tenaga kerja yang positif pada sektor pariwisata.

Berdasarkan Gambar 1, sektor pariwisata di Jawa Barat berperan besar terhadap produktivitas masyarakat yang dapat membantu dalam mengurangi pengangguran. Namun pertumbuhan tenaga kerja sektor parwisata masih jauh dibawah pertumbuhan tenaga kerja sektor lainnya. Penyerapan tenaga kerja sektor 
pariwisata lebih rendah dibandingkan dengan sektor listrik, gas dan air minum, sektor jasa dan sektor keuangan lainnya (terlihat pada Gambar 2). Perkembangan yang signifikan dari tenaga kerja sektor pariwisata tidak secepat sektor listrik, gas dan air minum, sektor bangunan dan sektor jasa keuangan. Rata-rata pertumbuhan penyerapan tenaga kerja sektor pariwisata berada di posisi lima terbawah dari sembilan sektor lainnya.

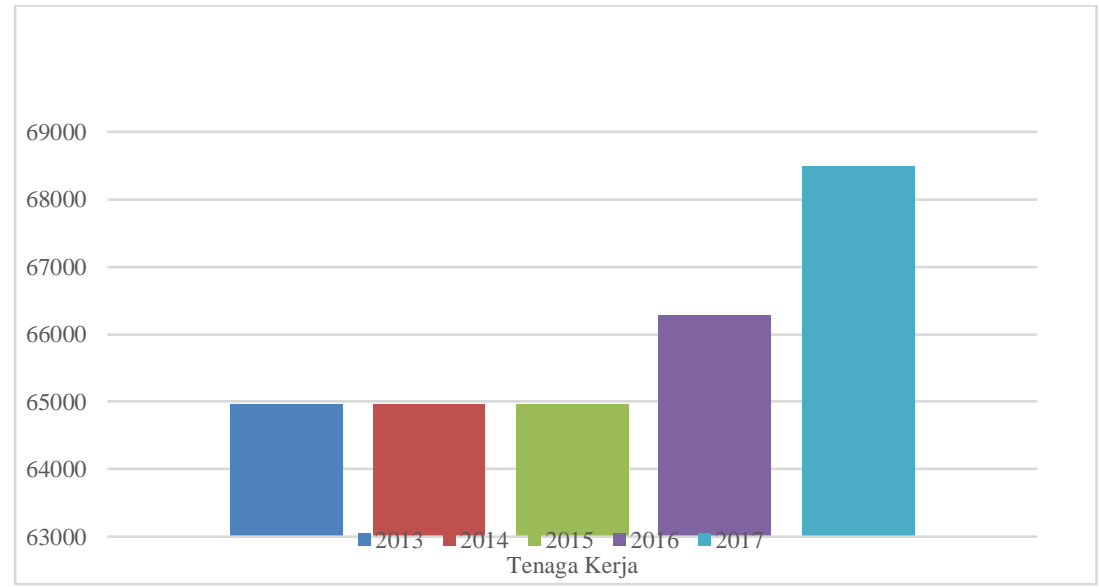

Sumber : Dinas Kebudayaan dan Pariwisata Provinsi Jawa Barat.

\section{Gambar 1.}

Penyerapan Tenaga Kerja Sektor Pariwisata Provinsi Jawa Barat Tahun 2011 - 2017 (Jiwa)

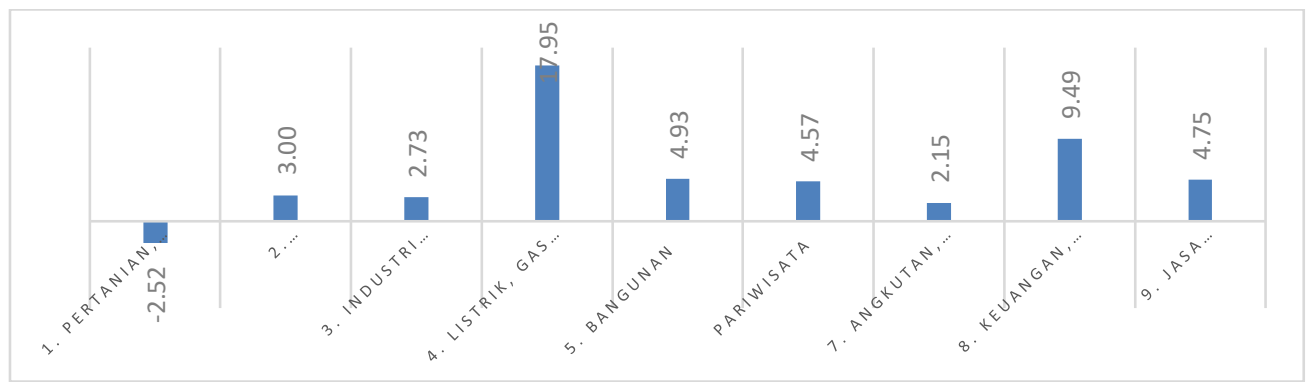

Sumber: Dinas Tenaga Kerja dan Transmigrasi Provinsi Jawa Barat, diolah.

Gambar 2.

Pertumbuhan Tenaga Kerja per Lapangan Usaha di Jawa Barat Periode 2011-2017 (Rata-Rata) 
Penyerapan tenaga kerja dapat dipengaruhi oleh beberapa indikator seperti jumlah hotel, kedatangan wisatawan mancanegara, upah minimum dan pendapatan masyarakat. Indikator tersebut setidaknya dapat mengangkat sektor pariwisata baik disisi pertumbuhan output pariwisata dan penyerapan tenaga kerja. Dilihat dari sisi jumlah wisatawan yang berkunjung ke objek wisata Jawa Barat mengalami peningkatan dalam setiap tahunnya. Pada Gambar 3, wisatawan domestik memiliki pertumbuhan yang cukup besar untuk berkunjung ke daerah pariwisata Jawa Barat.

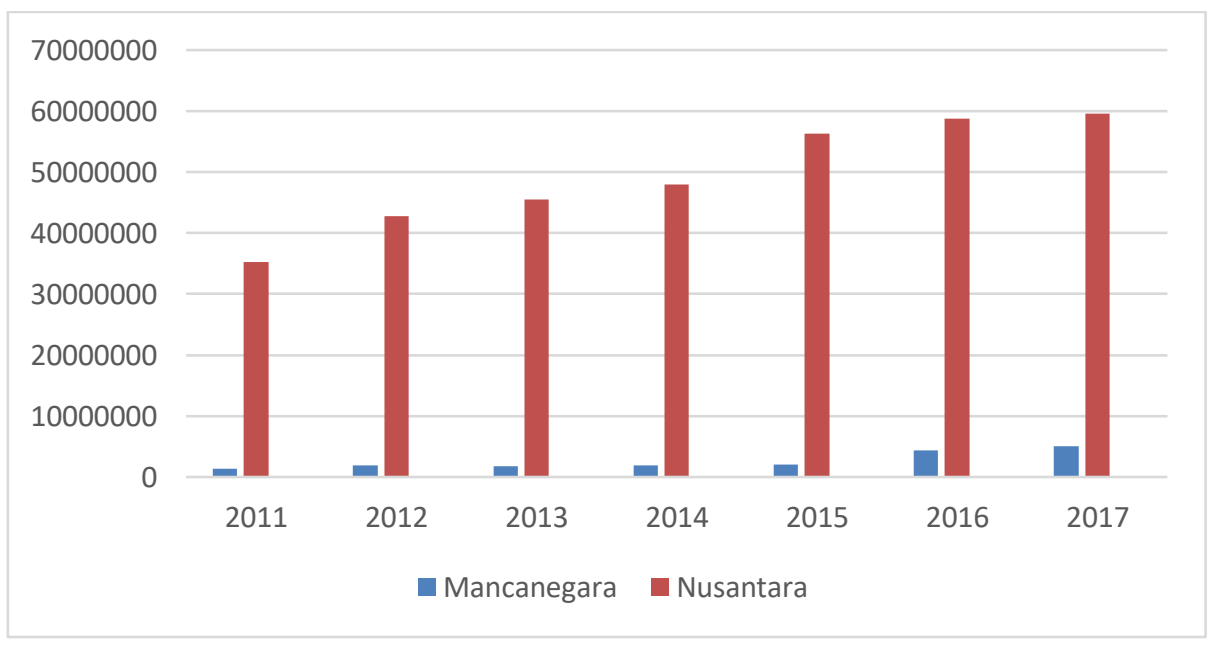

Sumber : Dinas Kebudayaan dan Pariwisata Provinsi Jawa Barat.

Gambar 3.

\section{Jumlah Kedatangan Wisatawan Provinsi Jawa Barat}

Pada Gambar 3 di atas, menunjukkan peningkatan jumlah wisatawan ini seharusnya dapat mengangkat penyerapan tenaga kerja di sektor pariwisata. Permintaan sektor pariwisata yang cukup besar seharusnya mempengaruhi peningkatan input pariwisata seperti tenaga kerja pariwisata di Jawa Barat. 
Beberapa penelitian yang menjelaskan tenaga kerja pariwisata seperti penelitian Aguayo Eva (2011) menjelaskan sektor pariwisata dapat meningkatkan lapangan kerja dan pertumbuhan ekonomi daerah melalui jumlah dari semua barang dan jasa yang dihasilkan pada sektor pariwisata. Penelitian PavliĆ, et al.(2012), peningkatan sektor pariwisata dapat mempengaruhi peningkatan tenaga kerja dan mendorong perekonomian daerah. Penelitian ini akan mencoba melihat pengaruh indikator-indikator yang dapat mempengaruhi penyerapan tenaga kerja di sektor pariwisata. Besaran nilai indikator yang terhubung dengan sektor pariwisata setidaknya akan mempengaruhi perkembangan tenaga kerja sektor pariwisata.

Penelitian lainnya yang dilakukan oleh Vrinda Kadiyali \& Renáta Kosová (2012) menunjukkan bahwa jumlah wisatawan yang datang dan yang menetap di suatu daerah wisata akan meningkatkan permintaan berbagai barang dan jasa lokal, baik dengan belanja langsung atau tidak langsung dengan pengaruh eksternalitas yang diakibatkan oleh kegiatan ekonomi pariwisata. Penelitian ini menggunakan data 43 area statistik metropolitan Amerika Serikat selama 19872006, dengan menggunakan metode Ordinary Least Square (OLS) dan model panel data dinamis, hasil penelitian ini menunjukkan bahwa jumlah kamar hotel yang terjual berhubungan positif dengan penyerapan tenaga kerja, variabel Gross Domestic Regional Product (GDRP) juga berhubungan positif dengan penyerapan tenaga kerja.

Pada penelitian ini akan membahas faktor-faktor yang mempengaruhi penyerapan tenaga kerja seperti jumlah wisatawan, upah minimum, jumlah kamar 
hotel dan output (PDRB) pariwisata di Jawa Barat. Provinsi Jawa Barat selama ini menjadi satu diantara objek wisata yang terkenal di Indonesia. Namun, dalam sisi input tenaga kerja pariwisata masih sangat rendah dibandingkan sektor ekonomi lainnya. Tujuan dalam penelitian ini untuk menganalisa pengaruh dari jumlah wisatawan, upah minimum, jumlah kamar hotel dan output (PDRB) pariwisata terhadap penyerapan tenaga kerja di Jawa Barat.

\section{METODE PENELITIAN}

Penelitian ini menggunakan analisis deskriptif dan kuantitatif dari Kabupaten/Kota di Provinsi Jawa Barat. Ruang lingkup dalam penelitian ini yaitu sebanyak 25 Kabupaten/Kota di Jawa Barat dengan periode 2013-2017 dalam bentuk panel data. Adapun sumber data didapat dari Dinas Pariwisata dan Budaya Provinsi Jawa Barat dan Badan Pusat Statistik Jawa Barat. Model penelitian yang digunakan yaitu model Generalized Least Square. Beberapa variabel yang mempengaruhi penyerapan tenaga kerja dalam penelitian ini seperti PDRB sektor pariwisata, jumlah kamar hotel (terpakai), jumlah wisatawan mancanegara dan domestik dan upah minimum. Persamaan pada penelitian ini adalah sebagai berikut.

$\mathrm{TK}=\mathrm{f}$ (Wisatawan, Upah Minimum, kamar hotel, PDRB Pariwisata).

dengan demikian, model penelitian penyerapan tenaga kerja menjadi :

$\operatorname{LnTK}_{i t}=\mathfrak{a}_{0}+\beta_{1} \operatorname{LnWis_{it}}+\beta_{2} \operatorname{LnUM}_{i t}+\beta_{3} \operatorname{LnHTL}_{i t}+\beta_{4} \operatorname{LnPDRBPAR_{it}}+$ $\mu_{i t} \ldots \ldots(1)$ 
Dalam model diatas, penyerapan tenaga kerja $(T K)$ dipengaruhi oleh jumlah wisatawan (Wis), upah minimum $(U M)$, jumlah kamar terpakai $(H T L)$ dan PDRB pariwisata (PDRBPAR). a merupakan intersept dan $\beta_{1}-\beta_{4}$ adalah koefisien variabel independen. Dalam penelitian ini dilakukan uji t dan uji f serta pengujian asumsi klasik. Kemudian dalam penelitian dilakukan pengujian Chow test dan Hausman test. Chow test untuk menguji model tersebut menggunakan model common effect atau fixed effect, sedangkan Hausman test untuk mengetahui bahwa model penelitian menggunakan model fixed effect atau random effect.

\section{HASIL DAN PEMBAHASAN}

Hasil penelitian penyerapan tenaga kerja sektor pariwisata terlebih dahulu dilakukan pengujian chow test, hasil dari uji chow test adalah Chi-Sq Stat. 778.461 Prob. 0.000, nilai dari Chow test Prob berada dibawah 5\% maka persamaan penyerapan tenaga kerja sektor pariwisata menggunakan fixed effect. Kemudian hasil Hausman test yaitu Chi Sq.Stat : 19.545 dan Prob : 0.000, hasil uji hausman pada Prob sebesar 0.000 dibawah 5\% maka persamaan model penyerapan tenaga kerja pariwisata menggunakan fixed effect. Model yang digunakan adalah model Generalized Least Square untuk mengoreksi adanya autokorelasi dan heterokedastisitas (Gujarati \& Damodar, 2006). Hasil perhitungan dengan model Generalized Least Square dapat dilihat pada Tabel 1.

Hasil estimasi pada Tabel 1 diatas hanya satu variabel independen yang tidak mempengaruhi penyerapan tenaga kerja yaitu PDRB sektor pariwisata. Sedangkan variabel independen lainnya mempengaruhi signifikan terhadap 
penyerapan tenaga kerja sektor pariwisata.

Tabel 1.

Hasil Persamaan Penyerapan Tenaga Kerja Sektor Pariwisata Kab.Kota di Jawa Barat

Dependent Variabel : LNTK

\begin{tabular}{cccc}
\hline Variabel & Koefisien & t-Stat & Prob. \\
\hline \hline C & 9.535647 & 20.3246 & 0.000 \\
LNWIS & 0.005426 & 1.742192 & 0.085 \\
LNUM & 0.062965 & 1.667169 & 0.099 \\
LNHTL & 0.030503 & 3.459942 & 0.001 \\
LNPDBPAR(-1) & 0.096453 & 0.78399 & 0.435 \\
\hline Adjusted R-squared & 0.998913 & & \\
F-statistic & 4070.191 & & \\
Prob(F-statistic) & 0 & &
\end{tabular}

Hasil dari nilai koefisien dari jumlah kedatangan wisatawan sebesar 0.005426, jadi setiap peningkatan jumlah wisatawan sebesar satu persen akan meningkatkan jumlah tenaga kerja pariwisata yang terserap di Jawa Barat sebesar $0.005426 \%$ dengan asumsi cateris paribus. Hasil tersebut sesuai dengan penelitian Kadiyali dan Kosová (2012), jumlah wisatawan yang datang akan meningkatkan permintaan berbagai barang maupun jasa lokal dan mempengaruh eksternalitas oleh aktivitas ekonomi pariwisata. Peningkatan kegiatan pariwisata akan berdampak penyerapan tenaga kerja didaerah tersebut. Penelitian Pavlić, et al. (2013) menjelaskan adanya pengaruh kedatangan wisatawan asing terhadap tenaga kerja sektor pariwisata di Kroasia yang memberikan efek positif terhadap perekonomian negara tuan rumah. Besaran nilai kedatangan jumlah wisatawan tidak memberikan peranan yang terlalu tinggi terhadap penyerapan tenaga kerja sektor pariwisata di Jawa Barat. Pertumbuhan wisatawan belum memberikan efek 
yang begitu besar terhadap penyerapan tenaga kerja sektor pariwisata. Hal ini terlihat dari penjelasan sebelumnya dalam pendahuluan bahwa penyerapan tenaga kerja sektor pariwisata masih dibawah sektor ekonomi lainnya.

Peningkatan jumlah wisata yang mengunjungi objek wisata terus meningkat maka akan mendorong pengusaha untuk berinvestasi pada sarana dan prasarana di daerah wisata di Jawa Barat yang akan meningkatkan jumlah tenaga kerja. Perkembangan jumlah wisatawan yang tinggi akan membutuhkan layanan akomodasi yang memadai seperti hotel, cottage dan tempat penginapan. Layanan akomodasi menghasilkan penyerapan tenaga kerja untuk memenuhi usaha akomodasi. Kemudian dengan adanya jasa travel untuk memberikan kemudahan perjalanan wisata dan semakin banyak layanan jasa travel akan membutuhkan tenaga kerja yang diserap didalamnya. Besarnya jumlah wisatawan akan berdampak terhadap penambahan layanan akomodasi (hotel, restoran, cottage dan tempat penginapan) dan biro perjalanan sehingga akan mempengaruhi penyerapan tenaga kerja. Peningkatan jumlah wisatawan akan berdampak baik dalam mempengaruhi kesempatan kerja di bidang pariwisata.

Objek wisata yang didukung oleh layanan akomodasi dan transportasi pada akhirnya akan bermuara pada penciptaan lapangan kerja yang dapat menambah tenaga kerja di bidang pariwisata. Perkembangan jumlah wisatawan akan memperbesar pengeluaran wisatawan yang dapat meningkatkan pendapatan masyarakat di daerah wisata Jawa Barat. Pengeluaran wisatawan umumnya digunakan untuk mengkonsumsi layanan wisata. Besarnya konsumsi wisatawan 
dalam mendapatkan layanan wisata akan memacu penyerapan tenaga kerja pariwisata di Jawa Barat. Semakin lama wisatawan berkunjung maka semakin besar jumlah uang yang dikeluarkan. Jumlah uang yang dikeluarkan untuk mendapatkan kepuasan dalam kegiatan wisata seperti hotel, konsumsi, transportasi maupun objek wisata. Prilaku wisatawan yang konsumtif akan berdampak terhadap jumlah uang beredar dan pendapatan sektor pariwisata. Pendapatan berasal dari wisatawan menjadi modal untuk memperbaiki atau peningkatan fasilitas objek wisata sehingga akan menarik investor untuk menanamkan modal di sektor pariwisata. Banyak para investor yang tertarik untuk menanamkan modalnya akan berdampak kepada penyerapan tenaga kerja. Hal ini tenaga kerja sangat dibutuhkan dikarenakan adanya lapangan kerja di sektor pariwisata.

Upah minimum mempengaruhi positif dan signifikan terhadap penyerapan tenaga kerja sektor pariwisata di Kabupaten/Kota Jawa Barat. Nilai koefisien upah minimum (UM) sebesar 0.062965. Dari nilai koefisien upah minimum menjelaskan setiap kenaikan upah minimum sebesar satu persen akan meningkatkan tenaga kerja sebesar $0.062965 \%$ dengan asumsi cateris paribus. Upah merupakan penerimaan individu sebagai imbalan dari hasil kerja yang diberikan oleh perusahaan dan disesuaikan dengan perundangan pemerintah. Penelitian Kadiyali \& Kosová (2012) yang menjelaskan bahwa variabel upah minimum sebagai variabel kontrol yang tidak termasuk pada sektor pariwisata tetapi termasuk pada faktor-faktor penyerapan tenaga kerja. Upah minimum memiliki berpengaruh positif terhadap penyerapan tenaga kerja, hal ini 
dikarenakan kenaikan upah minimum dapat menyebabkan peningkatan tenaga kerja yang terserap.

Tingkat upah merupakan hasil dari permintaan dan penawaran, dimana perubahan tingkat upah dapat mempengaruhi terhadap tingkat konsumsi masyarakat. Rendahnya pembelian dari konsumen akan memaksa produsen untuk mengurangi jumlah produksinya yang disesuaikan dengan tenaga kerja yang dibutuhkan. Besarnya output pariwisata akan mempengaruhi tingkat output marginal dan tingkat upah, sehingga kenaikan upah dapat meningkatkan penyerapan tenaga kerja. Adanya peningkatan upah maka pengusaha berupaya untuk meningkatkan jumlah unit usahanya. Penambahan unit usaha akan menambah jumlah tenaga kerja, jadi dapat dikatakan objek wisata Jawa Barat yang semakin bertambah merupakan hasil pengusaha dalam meningkatkan unit usaha yang dapat meningkatkan tenaga kerja. Setiap perusahaan jasa pariwisata yang dapat meningkatkan produk wisata, diindikasikan akan menambah jumlah tenaga kerja.

Upah minimun bertujuan melindungi para pekerja agar tingkat upah tidak terlalu rendah pada saat tingkat penawaran tenaga kerja tinggi dan permintaan tenaga kerja rendah menjadikan tingkat upah mengalami penurunan. Tingkat upah minimum bersifat mengikat dan tidak mengikat, kondisi yang mengikat pada saat upah minimum lebih rendah dibandingkan upah keseimbangan pasar tenaga kerja mengalami penurunan. Sedangkan kondisi tidak mengikat terjadi apabila tingkat upah minimum lebih tinggi dibandingkan tingkat 
upah keseimbangan pasar tenaga kerja. Tingkat upah minimum mempengaruhi positif terhadap penyerapan tenaga kerja di Jawa Barat, maka kecenderungan tingkat upah minimum yang terjadi lebih bersifat tidak mengikat. Kecenderungan yang terjadi pada upah minimum di Jawa Barat dalam kondisi tidak mengikat, dikarenakan tingkat upah minimum berdampak terhadap penyerapan tenaga kerja di Jawa Barat. Hal ini upah minimum berlaku untuk seluruh sektor ekonomi terutama bagi perusahaan yang mengutamakan padat karya. Potensi pariwisata yang terus berkembang di Jawa Barat menarik para perusahaan untuk mendirikan jasa akomodasi dengan cara menaikan upah untuk mendorong peningkatan tenaga kerja pariwisata. Usaha mendorong lebih banyak tenaga kerja dikarenakan perusahaan membutuhkan tenaga kerja sebagai input produksi pada industri pariwisata.

Selanjutnya, pengaruh jumlah kamar (HTL) mempengaruhi positif dan signifikan terhadap jumlah tenaga kerja. Nilai koefisien jumlah kamar terpakai sebesar 0.030503. Nilai Koefisien tersebut menjelaskan setiap kenaikan satu persen jumlah kamar terpakai (HTL) akan meningkatkan jumlah tenaga kerja sebesar $0.030503 \%$ dengan asumsi cateris paribus. Menurut Kadiyali dan Kosová (2012), variabel jumlah kamar hotel yang terjual berpengaruh positif dan signifikan terhadap penyerapan tenaga kerja. Peneltian Eva (2011) menunjukkan dampak positif dari sektor akomodasi terhadap lapangan kerja, kemudian penelitian Pavlić, et al. (2013), menjelaskan industri perhotelan, restoran dan kafe, agen travel beperan penting dalam meningkatkan penyerapan tenaga kerja di Kroasia. Bertambahnya jumlah kunjungan wisatawan akan berdampak terhadap 
permintaan konsumen pada fasilitas penginapan dimana salah satunya dengan menambah jumlah kamar hotel.

Hotel merupakan suatu kegiatan usaha yang berorientasi profit dengan menawarkan berbagai fasilitas seperti restoran, kamar tidur sehingga memerlukan padat modal maupun padat karya. Pertambahan jumlah wisatawan membuat pengusaha hotel untuk menambah fasiltas hotel diantaranya penambahan jumlah kamar hotel. Penambahan jumlah kamar hotel mengakibatkan penambahan perawatan kamar hotel yang berdampak terhadap peningkatan tenaga kerja. Penambahan jumlah hotel akibat peningkatan permintaan wisatawan dalam mengkonsumsi dan akomodasi yang didukung oleh peningkatan modal maupun tenaga kerja. Adanya perhotelan menjadi penggerak pembangunan daerah dan memberikan kontribusi terhadap sektor pariwisata melalui peningkatan tenaga kerja dan jumlah kamar.

Sementara itu, output pariwisata (PDRB) tidak mempengaruhi secara signifikan terhadap tenaga kerja pariwisata di Jawa Barat. Daya dukung pariwisata yang rendah seperti sarana publik maupun fasilitas pariwisata akan menurunkan output pariwisata di Jawa Barat. Selain itu perkembangan output pariwisata bergantung terhadap besaran jumlah wisatawan sehingga penyerapan tenaga kerja akan menunggu dampak antara output pariwisata dan jumlah wisatawan.

\section{SIMPULAN DAN SARAN}

Penelitian ini menyimpulkan beberapa hasil yang dianalisis melalui pengaruh variabel bebas (jumlah wisatawan, upah minimum, jumlah kamar hotel 
dan PDRB pariwisata). Jumlah wisatawan mempengaruhi signifikan terhadap penyerapan tenaga kerja sektor pariwisata, namun pengaruh jumlah wisatawan belum memberikan dampak dan kontribusi yang cukup besar terhadap peningkatan tenaga kerja sektor pariwisata di Kabupaten/Kota Jawa Barat. Dengan demikian, adanya peningkatan jumlah wisatawan dengan menumbuhkan objek wisata yang ada di daerah Jawa Barat sangat penting dilakukan. Peningkatan objek wisata akan memacu pertambahan wisatawan yang dapat mempengaruhi layanan akomodasi maupun transportasi. Penambahan layanan akomodasi akan mendorong peningkatan tenaga kerja di sektor pariwisata.

Begitu juga dengan upah minimum dan jumlah kamar hotel mempengaruhi signifikan terhadap tenaga kerja sektor pariwisata di Kabupaten/Kota Jawa Barat. Peningkatan upah dapat meningkat apabila para pengusaha pariwisata di Jawa Barat dapat menjual hasil jasa yang lebih baik. Peningkatan output pariwisata akan mempengaruhi perubahan output dan upah sehingga berdampak terhadap penyerapan tenaga kerja. Permintaan pariwisata akan mempengaruhi layanan akomodasi seperti hotel, restoran dan transportasi. Semakin besar permintaan kunjungan wisatawan maka pengusaha akan menambahkan jumlah hotel termasuk jumlah kamar hotel. Oleh karena itu, penambahan jumlah kamar hotel akan mempengaruhi penyerapan tenaga kerja yang lebih besar. Variabel PDRB pariwisata yang tidak mempengaruhi secara signifikan terhadap tenaga kerja sektor pariwisata. Pada umumnya (25 Kabupaten/Kota di Jawa Barat), variabel pendukung sektor pariwisata belum dapat memberikan hasil yang lebih baik dalam penyerapan tenaga kerja sektor pariwisata di Jawa Barat. Kemudian 
peningkatan output pariwisata tidak berdampak langsung mempengaruhi penyerapan tenaga kerja dikarenakan output pariwisata bergantung dari perkembangan jumlah wisatawan.

\section{REFERENSI}

Arsyad, Lincolin. (1999). Pengantar Perencanaan dan Pembangunan Ekonomi Daerah. BPFE Yogyakarta

Burkart, A.J. dan Medlik, S. 1987. . L. (1987). Tourism, Past, Present, and Future, (London).

Gujarati Damodar. (2006). Basic Econometrics. (Mac Graw Hill Companies, Ed.) (4th ed.). New York.

Hidayat, G. (2017). Analisis Faktor-Faktor Yang Mempengaruhi Keputusan Permintaan KPR Pada Bank Syariah Di Kabupaten Sumedang. Economics Development Analysis Journal, 8(2), 129-137.

Kadiyali, V., \& Kosová, R. (2013). Inter-industry employment spillovers from tourism inflows. Regional Science and Urban Economics, 43(2), 272-281. https://doi.org/10.1016/j.regsciurbeco.2012.07.006

Kusumaningrum, D. (2009). Persepsi Wisatawan Nusantara Terhadap Daya Tarik Wisata Di Kota Palembang. Universitas Gadjah Mada.

Maulana, A. (2016). Pengaruh kunjungan wisatawan mancanegara dan perjalanan wisatawan nusantara terhadap penyerapan tenaga kerja sektor pariwisata di indonesia. Jurnal Kepariwisataan Indonesia, 11(1), 119-144.

Park, H. M. (2015). Linear regression models for panel data using SAS, Stata, LIMDEP, and SPSS.

PavliĆ, I., ToliĆ, M., \& Svilokos, T. (2012). Impact of Tourism on the Employment in Croatia. Wseas.Us, (Figure 1), 219-224.

Pitana, I. G. dan P. G. G. (2005). Sosiologi Pariwisata.

Ritchie, J., \& Crouch, G. (2003). The Competitive Destination: A Sustainable Tourism Perspective.

Sipayung, K. (2010). Analisa Penerimaan Pariwisata Dan Faktor-Faktor Yang Mempengaruhi Di Sepuluh Kabupaten/Kota Di Provinsi Sumatera Utara Periode 2005 - 2010, 9(1), 76-99. 
Adhitya Wardhana, Bayu Kharisma dan Citra Triaryanti. Determinan Penyerapan Tenaga

Smith, S. (1998). Tourism Analysis: A Handbook. England: Longman Group.

Vanhove, N. (2005). The Economic of Tourism Destination.

Wahab, S. (2003). Classification Of Tourism. Manajemen Kepariwisataan.

Wei, X., Qu, H., \& Ma, J. (2009). Modeling Tourism Employment Growth-An Application in China. 2009 ICHRIE Conference.

Wooldridge, J. M. (2006). Introductory Econometrics. Economica (Vol. 42). https://doi.org/10.2307/2553001

WTTC. (2015). Travel\& Tourism: Economic Impact 2015.

Yoeti, A. O. (1996). Pengantar Ilmu Pariwisata. Angkasa. Bandung. 